\title{
Mapping and characterization of intensity in land use by pasture using remote sensing
}

\author{
Arthur T. Calegario ${ }^{1}$, Luis F. Pereira ${ }^{2}$, Silvio B. Pereira ${ }^{1}$, Laksme N. O. da Silva ${ }^{3}$, \\ Uriel L. de Araújo² \& Elpídio I. Fernandes Filho² \\ ${ }^{1}$ Universidade Federal de Viçosa/Departamento de Engenharia Agrícola. Viçosa, MG, Brasil. E-mail: tcalegario@gmail.com (Corresponding author) - \\ ORCID: 0000-0002-1921-5234; silviopereira.ufv@gmail.com - ORCID: 0000-0001-8491-144X \\ ${ }^{2}$ Universidade Federal de Viçosa/Departamento de Solos. Viçosa, MG, Brasil. Email: pereira.flavioluis@gmail.com - ORCID: 0000-0002-4898-0525; \\ uriel.laurentiz@gmail.com - ORCID: 0000-0001-9709-3714; elpidio.solos@gmail.com - ORCID: 0000-0003-2440-8329 \\ ${ }^{3}$ Universidade Federal de Viçosa/Departamento de Engenharia Florestal. Viçosa, MG, Brasil.E-mail: lk.narayana.91@gmail.com - ORCID: 0000-0002-2350-7512
}

ABSTRACT: The current demand for food has been met through the exploitation of natural reserves. Brazil
has $26 \%$ of its extension occupied by agricultural uses, $62 \%$ of which are pastures. Degraded pastures have
greater land use intensity than well-managed pastures, leading to greater degradation of the environment.
Land use classification systems consider that pastures are well managed, a misconception for the Brazilian
reality. Based on this approach, it was aimed to develop a methodology for mapping the intensity of land use
by pasture via remote sensing. The method of mapping was developed and validated in basins with different
soil and climatic characteristics. Three calibrations were performed based on NDVI values to ascertain the
influence on the results, being evaluated from the field campaigns and the kappa and weighted kappa indices.
The kappa and weighted kappa indices presented reasonable and moderate agreement, respectively. The
results were considered as satisfactory for the three calibrations, evidencing that the degree of degradation
of the pastures can be estimated in a simple way by remote sensing. The Limoeiro River Basin has around
$46.9 \%$ of pastures, at least, heavily degraded and $96.6 \%$ with some degree of degradation, which contributes to
degradation of the natural resources and reduction of livestock farming and economic potential of the basin.

Key words: soil and water conservation, GIS, kappa and weighted kappa indices

\section{Mapeamento e caracterização da intensidade de uso da terra pelas pastagens usando sensoriamento remoto}

RESUMO: A demanda atual por alimentos tem sido atendida por meio da exploração das reservas naturais. O Brasil apresenta $26 \%$ da sua extensão ocupada por usos agropecuários, sendo $62 \%$ desses, pastagens. Pastagens degradadas apresentam maior intensidade de uso da terra do que pastagens bem manejadas, levando à maior degradação do meio ambiente. Os sistemas de classificação da capacidade de uso de terra consideram que as pastagens se apresentam bem manejadas, consideração equivocada para a realidade brasileira. Baseado nesse enfoque, objetivou-se apresentar e validar uma metodologia de mapeamento da intensidade de uso da terra exercida por pastagens via sensoriamento remoto. O método de mapeamento foi desenvolvido e validado em bacias com características edafoclimáticas distintas. De posse da metodologia, três calibrações foram realizadas, com base nos valores de IVDN, para averiguar a influência nos resultados, sendo avaliados a partir das campanhas de campo e dos índices kappa e kappa ponderado. Os índices kappa e kappa ponderado apresentaram concordância razoável e moderada, respectivamente. Os resultados foram considerados satisfatórios para as três calibrações, evidenciando que o grau de degradação das pastagens pode ser estimado de maneira simples por sensoriamento remoto. A Bacia do Rio Limoeiro apresenta em torno de 46,9\% das pastagens, no mínimo, fortemente degradadas; e 96,6\% com algum grau de degradação, o que contribui para degradação dos recursos naturais e redução do potencial pecuário e econômico da bacia.

Palavras-chave: conservação de solo e água, SIG, índices kappa e kappa ponderado 


\section{INTRODUCTION}

Historically, the demand for food, water and other resources has been met partially by the exploitation of natural resources, generating profound changes in the structure of the ecosystems, such as the transformation of approximately $24 \%$ of the Earth's surface into cultivated systems (MEA, 2005). In Brazil, an estimation performed by Dias et al. (2016) indicates that, in 2012, $26 \%$ of the territorial extension was occupied with agricultural activities, $62 \%$ with pastures and $38 \%$ with agricultural uses.

The same form of land use may lead to higher or lower impact on natural resources, depending on the management adopted (Oudenhoven et al., 2015; Rocha Júnior et al., 2017a; Schneider et al., 2017), which demonstrates the importance of knowing the land use intensity when one wants to understand the level of impact caused by this occupation, i.e., its intensity of use.

According to Sambuichi et al. (2012), in 2006, areas occupied by pasture were 163 million ha, with 9.8 million ha of degraded pastures. INAES (2015) estimated that in the state of Minas Gerais only $4 \%$ of the pastures do not exhibit signs of degradation and that $43.5 \%$ would be heavily degraded for the year 2014.

Lepsch et al. (2015) suggested that lands should be classified into eight classes of capacity of use, and well-managed pastures may be implemented on lands of up to class VII. However, since it is known that this fact does not represent the Brazilian reality, it is necessary to characterize the state of the pastures which represent higher classes of use intensity.

Based on this approach and considering that remote sensing has been a tool used in studies on pasture degradation (INAES, 2015; Pereira et al., 2018), the objective was to present and validate a methodology to map and characterize the land use intensity exerted by pasture using remote sensing.

\section{Material and Methods}

The Basins of the São Bartolomeu and Limoeiro Rivers were selected as study areas and are respectively located in the southern and eastern portions of the Doce River Basin, situated in the states of Minas Gerais and Espírito Santo, Brazil (Figure 1). The São Bartolomeu River Basin was used in the development of the methodology, whereas the Limoeiro River Basin was used in its validation. According to Köppen's climate classification, the São Bartolomeu River Basin is located in a subtropical humid zone with dry winter, whereas the Limoeiro River Basin is located in the tropical monsoon zone (Alvarez et al., 2013).

The São Bartolomeu River Basin has a predominance of deep Latosols and, secondarily, Cambisols and Argisols originated from gneiss saprolites, whereas in the Limoeiro River Basin there is extensive dominance of Argisols and Litholic Neosols derived from ultrametamorphic granitoids (Brasil, 2010).

The database used consisted of images from Google Earth and LANDSAT 8 OLI. LANDSAT 8 images were those with codes 2170742015268 and 2160742015277 , acquired by the satellite on September 25 and October 4, 2015, respectively.

The dates were chosen based on the coincidence with the transition between dry and humid annual periods in the Doce River Basin, in order to identify the conditions of the pastures in the period with occurrence of water stress, low vegetation cover and the first rains (Figure 2). In addition, this period represents the time of highest environmental risks related to water erosion and loss of resources, and greater ease to find images with lower interference caused by cloudiness. The climatological stations used belong to the National Institute of Meteorology (INMET) and the stations considered were those from Viçosa (MG) and Caratinga (MG), which were the closest ones to the basins.
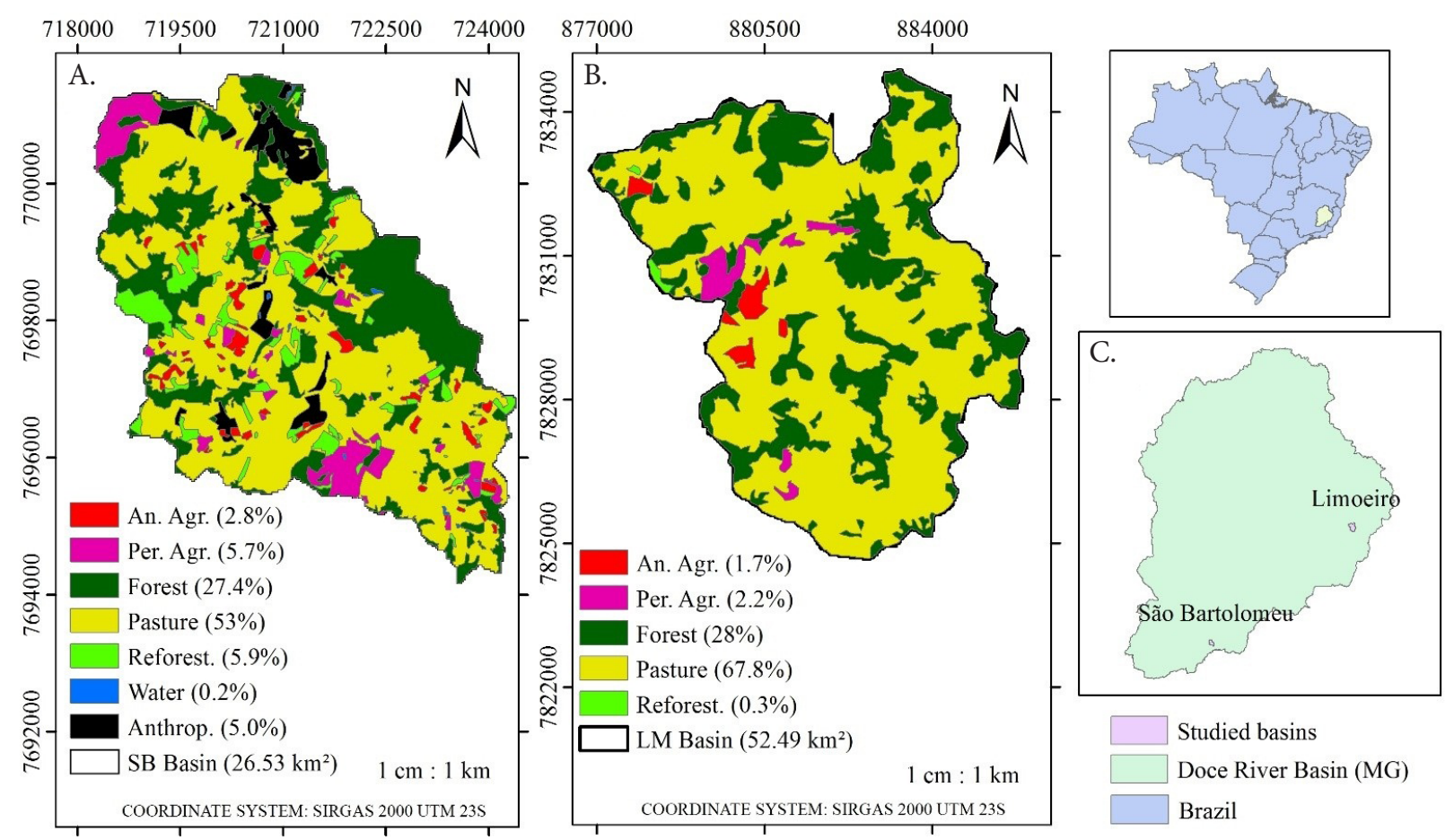

(An. Agr. - Annual agriculture; Per. Agr. - Perennial agriculture; Reforest. - Reforestation of commercial exploitation; Anthrop. - Anthropized area; SB. - São Bartolomeu; LM. - Limoeiro) Figure 1. Map of location and of land use and cover in the São Bartolomeu River Basin (A) and Limoeiro River Basin (B), located at the Minas Gerais (MG) portion of the Doce River Basin (C) 


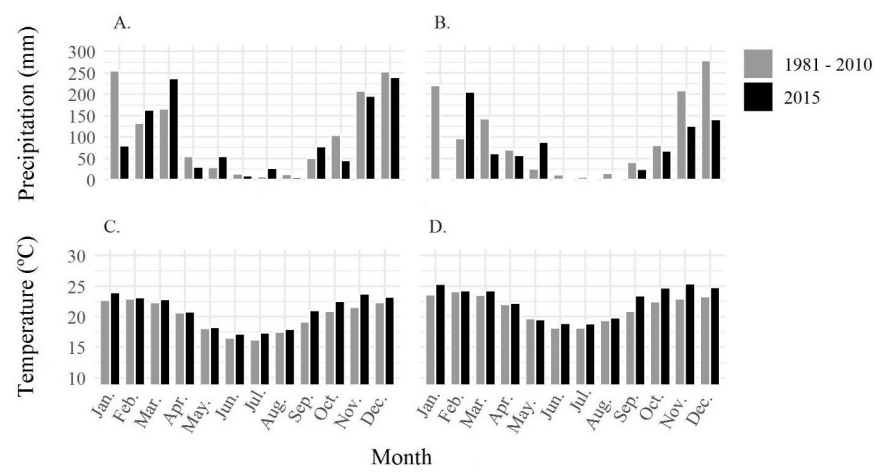

Figure 2. Mean monthly precipitation (1981 to 2010) and monthly precipitation of the year 2015 (A, B) and mean monthly temperature (1981 to 2010) and monthly temperature of the year 2015 (C, D) for the climatological stations located in the municipalities of Viçosa (A, C) and Caratinga, MG (B, D)

The maps of land use and cover (Figures 1A and B) were obtained by on-screen vectorization in the program ArcGis 10.2, based on the interpretation of Google Earth images.

The methodological development of mapping and characterization of the classes of land use intensity exerted by the pastures was carried out in the São Bartolomeu River Basin in two steps (Figure 3). The first one (Figure 3A) consisted in the modeling by remote sensing of the levels of use intensity exerted by the pastures, which allowed the identification of regions whose states of conservation were homogenous and distinct, and their visual characterization in the field. The process was repeated continuously until the results of modeling and characterization of classes of use intensity of the pastures were considered as satisfactory.

The levels of land use intensity (LUI) by the pastures were modeled using the Normalized Difference Vegetation Index (NDVI), Eq. 1, which has been widely applied in studies on differentiation of vegetation through remote sensing, for allowing expressive correlation with evaluation parameters commonly used in the characterization of vegetation stratum, such as phytomass, leaf area, photosynthetic activity, yield and percentage of vegetation cover (INAES, 2015; Bernardi et al., 2017; Pereira et al., 2018).

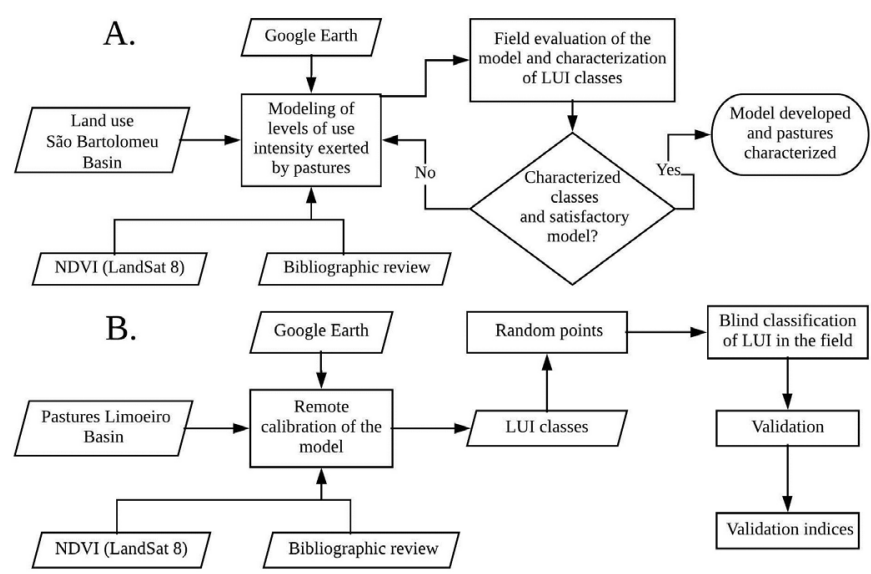

LUI - Land use intensity

Figure 3. Modeling and characterization of land use intensity (LUI) by pastures in the São Bartolomeu River Basin to obtain an adequate model (A) and remote calibration of the model and its field validation in the Limoeiro River Basin (B)

$$
\mathrm{NDVI}=\frac{\mathrm{NIR}-\mathrm{RED}}{\mathrm{NIR}+\mathrm{RED}}
$$

where:

"RED" and "NIR" are the values of red and near infrared for each pixel, respectively.

The Eq. 1 returns values from -1 to 1 , so that the positive unit value is associated with a high vegetation cover, where all the red wavelength is absorbed to perform photosynthesis. After calculating the NDVI, its response was cut out using as masks areas classified as pastures.

Land use intensity by pastures was characterized mainly based on the soil cover rate, associated with canopy height and vigor of the plants because, according to Rocha Júnior et al. (2017b), the visual evaluation of these criteria is well correlated with soil physical and chemical quality. In addition, the land use intensity exerted by the pastures is linked to the vegetation cover provided by them (Oudenhoven et al., 2015; Rocha Júnior et al., 2017a).

Soil covering by the pasture is important because it provides protection against the impact of raindrops and cattle trampling, avoiding superficial sealing (Li et al., 2018) and compaction (Silva et al., 2003), respectively. Additionally, vegetation cover increases soil surface roughness (Rocha Júnior et al., 2016) and expresses root density. These characteristics influence water infiltration rate and storage in the soil, fertility, organic matter content and, therefore, resistance to erosive processes and maintenance of soil quality (Álvarez-Mozos et al., 2011; Rocha Júnior et al., 2016).

The classes of use intensity exerted by the pastures and the associated characteristics observed by the authors are presented in Table 1.

The number of classes chosen was eight, because it aims to adjust the classification to the land use capacity system presented by Lepsch et al. (2015). In addition, the class VIII was considered in order to reduce the subjectivity associated with the on-screen mapping, given the difficulty in distinguishing the point where 'capoeira' begins to be considered as forest. Thus, such decision was standardized for the entire area based on the NDVI.

Due to the large number of classes and gradual transition existing between them, there were frequent doubts in the field classification. Because of that, it was necessary to list secondary characteristics in order to reduce the subjectivity in this classification, for example, presence of trees, fires, inadequate techniques of planting and management, stage of erosion, compaction, among other aspects.

The field characterization carried out in the first step allowed obtaining a refined standardization by the five evaluators, with divergences of no more than one class of intensity between the different evaluators during the field campaigns.

The model for classifying the land use intensity exerted by the pasture, obtained in the first step, consisted of two steps: (i) identify NDVI values corresponding to exposed soil and forest based on Google Earth images and bibliographic review; 
Table 1. Classes of land use intensity exerted by the pasture

\begin{tabular}{|c|c|c|}
\hline Class & Denomination & Characteristics \\
\hline I & Exposed soil & Regions with large and/or numerous areas where there is complete exposure of the soil. \\
\hline II & Extremely degraded pastures & $\begin{array}{l}\text { Very low soil cover. There is presence of intense and explicit erosive processes, with great soil exposure } \\
\text { and surface horizon partially or completely eroded. Low presence of trees and absence of water and soil } \\
\text { management and conservation techniques, overgrazing conditions, frequent burning, and crop planting } \\
\text { utilizing non-conservationist techniques (such as downslope plowing and harrowing), can be secondary } \\
\text { criteria that help in the classification, if visual classification based only on soil cover rate is dubious. }\end{array}$ \\
\hline III & Heavily degraded pastures & $\begin{array}{l}\text { Low to medium soil cover. There is notable presence of erosive processes, with exposed soil in small spots } \\
\text { which alternate with vegetated areas that moderately cover the surface. }\end{array}$ \\
\hline IV & Moderately degraded pastures & $\begin{array}{l}\text { Medium to good cover. Signs of surface runoff capable of causing erosion. Can be characterized by a good } \\
\text { soil cover with colorless low-growing vegetation, such as bahiagrass, or by a more demanding cultivar, } \\
\text { with taller clumps, but still allowing for soil exposure at some points. }\end{array}$ \\
\hline V & Slightly degraded pastures & $\begin{array}{l}\text { Good cover, the pasture is able to reasonably protect the soil from accelerated erosion, preventing large } \\
\text { concentrations of surface runoff, as well surface sealing. Promotes water infiltration and good aggregation } \\
\text { of soil particles. }\end{array}$ \\
\hline VI & Conservationist pastures & Good cover, vigorous pasture, always tall, even when grazed. \\
\hline VII & $\begin{array}{l}\text { 'Capoeiras' and silvopastoral } \\
\text { systems }\end{array}$ & Abandoned pastures in initial process of natural regeneration or natural silvopastoral systems. \\
\hline VIII & Natural forests & Native forests or in advanced stage of recovery. \\
\hline
\end{tabular}

and (ii) divide the NDVI interval between exposed soil and forest into six classes of equal amplitude. Thus, eight classes of land use intensity were obtained (exposed soil - I, natural forest - VIII, and intermediate intervals - II to VII).

The second step (Figure 3B) consisted in applying the developed model in the Limoeiro River Basin. To evaluate the model's applicability in a completely remote manner, its application was performed by calibration exclusively over Google Earth images and, then, validation in the field. During the visual calibration, three maps of land use intensity exerted by the pasture were generated for evaluation with different NDVI intervals relative to exposed soil $(<0.21$ - Calibration $1 ;<0.22$ - Calibration 2 ; and $<0.23$ - Calibration 3 ) and with a common interval for forests ( $>0.78$ ). The map generated by Calibration 2 was chosen for validation because it had better visual adjustment over Google Earth images.

Validation was carried out by generating 40 points randomly distributed over the map obtained in Calibration 2, composing five points for each class. This calibration was considered because, according to the authors, it had the best adjustment to Google Earth images. The points were classified in the field by visual analysis, without consulting the digital mapping, which allowed both classifications to be compared by the kappa and weighted kappa indices, in order to evaluate the accuracy of the classifier compared to the reality in the field (Congalton \& Green, 2009). Then, the same points were used to validate the maps produced by calibrations 1 and 3 .

Weighted kappa was calculated because the error between two neighboring classes did not cause major problems, compared to the errors between classes with more distinct levels of degradation, especially because pastures exhibit expressive variations in terms of vegetation cover throughout the year (Aguiar et al., 2017) and due to the smaller difference between the impacts caused by close classes of land use intensity.

As suggested by Congalton \& Green (2009), the kappa index can be weighted, assigning weights to each type of error in the classification, which vary from 0 to 1 , where 1 is the weight associated with errors with no importance, showing maximum agreement between the classifier and the reality in the field, and 0 is associated with errors which arise from the confusion between two classes without correlation.

Thus, weight of 0.9 was adopted for errors between neighboring classes, i.e., errors of one class above or below, and weight of 0 was adopted for the other errors. Kappa index values were interpreted as suggested by Landis \& Koch (1977). Image classification and statistical calculations were carried out using the R software environment (R Core Team, 2018).

\section{Results AND Discussion}

Figure 4 highlights the sites in the Limoeiro River Basin used in the remote calibration of land use intensity from Google Earth images, where black circles indicate areas of exposed soil and the red circle indicates area of forest.

The NDVI value relative to the forest (0.78) was not variable, because higher values did not have any pixel related to the forest, which is not consistent with Google Earth images. On the other hand, lower values of NDVI for calibration of the forests led to large forest areas, which was not consistent with the observations in Google Earth either.

In relation to the NDVI values used to delimit the class of exposed soil, there was greater difficulty in choosing the value which best represented this class. However, it can be noted in Figure 4 that all values of calibration satisfactorily delimit the spot of exposed soil observed in the Google Earth image.

The image chosen to generate the random points for validation of the classification was that of Calibration 2 (Figure $4 \mathrm{~B}$ ), because of the spots of exposed soil better represented by this classification.

It can be observed that pastures with lower use intensity are located in the lower zone of the terrain because these areas have greater availability of water, which provides better conditions for plant development and more vigorous vegetation. On the other hand, pastures which exert higher use intensity are located in the middle and upper portion of the terrain.

Table 2 presents the percentages of area associated with each class of land use intensity and the kappa and weighted kappa indices obtained for the three calibrations. The class of 

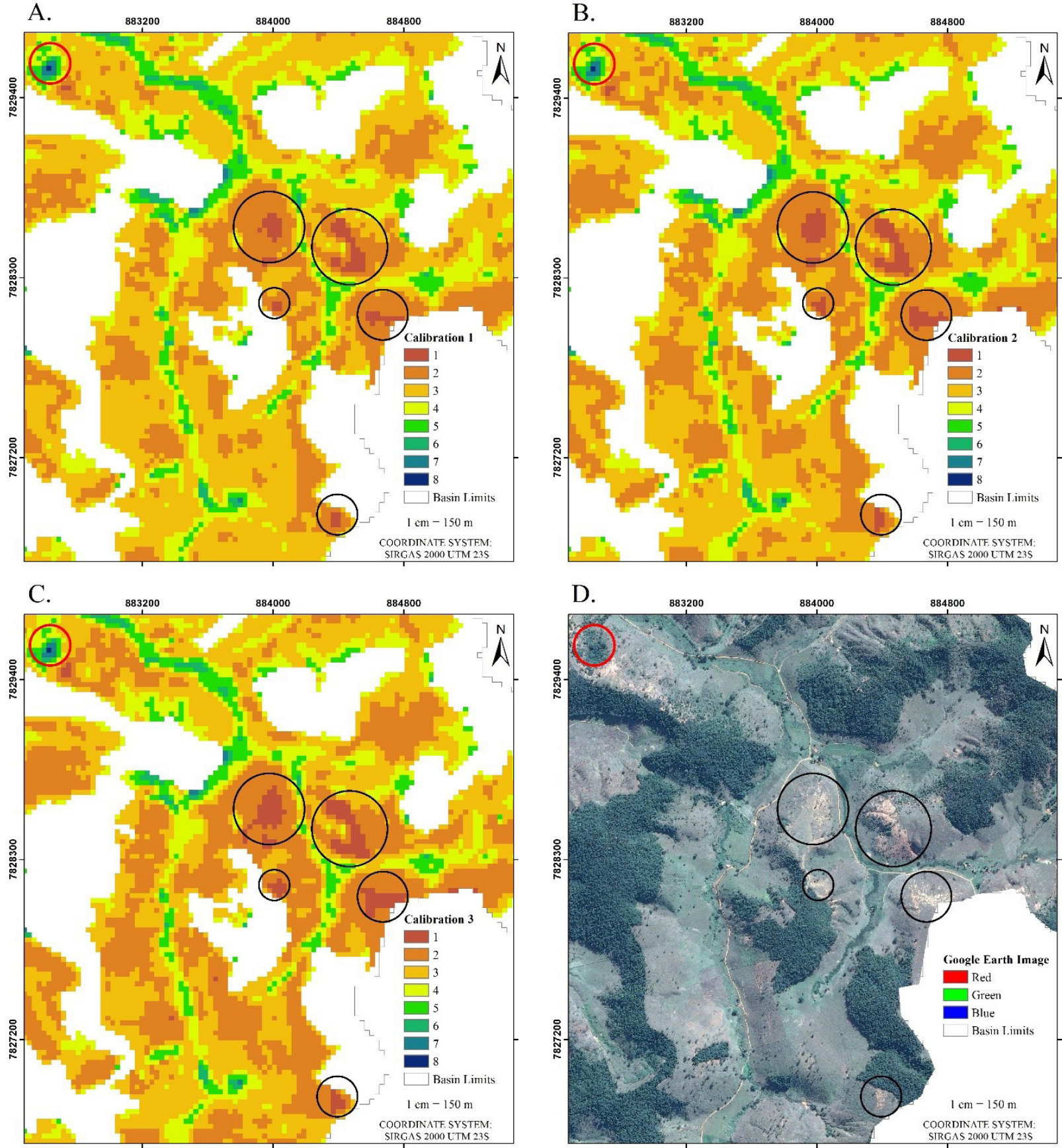

Basin Black and red circles indicate zones of exposed soil and forest used in the calibration, respectively

Figure 4. Map of classification of land use intensity by pasture according to the calibrations 1 (A), 2 (B) and 3 (C) and Google Earth image (D) of a portion of the Limoeiro River

Table 2. Percentage of areas occupied by different classes of use intensity by pastures and values of kappa and weighted kappa for the classifications performed

\begin{tabular}{|cccc|}
\hline Use intensity class & \multicolumn{3}{c|}{ Calibration } \\
\cline { 2 - 4 } and Validation indices & 1 & $\mathbf{2}$ & $\mathbf{3}$ \\
\cline { 2 - 4 } I & 0.3 & 0.5 & 0.8 \\
II & $17.3^{* * *}$ & $22.3^{* *}$ & $27.7^{* *}$ \\
III & $50.0^{*}$ & $46.9^{*}$ & $43.3^{*}$ \\
IV & $20.1^{* *}$ & $18.6^{* * *}$ & $17.2^{* * *}$ \\
V & 8.6 & 8.3 & 7.8 \\
VI & 3.0 & 2.9 & 2.7 \\
VII & 0.6 & 0.6 & 0.6 \\
VIII & 0 & 0 & 0 \\
kappa & 0.34 & 0.35 & 0.34 \\
weighted kappa & 0.62 & 0.66 & 0.62 \\
\hline
\end{tabular}

${ }^{*}$ Class of highest frequency; ${ }^{* *}$ Class of second highest frequency; ${ }^{* *}$ Class of third highest frequency highest predominance for the three calibrations was class III, and these conditions were observed in the field.

It can be noted that the absolute area of exposed soil from calibration 1 to calibration 3 is almost three times larger. However, this difference is not expressive compared to the total area because, for calibration 3 , the percentage of exposed soil represents $0.8 \%$ of the pastures.

The highest influence of calibration values is observed in the classes II, III and IV, causing the class of second highest frequency to change from IV, in calibration 1 , to II in calibrations 2 and 3. This behavior is explained by the fact that most NDVI values observed in the pastures range from 0.25 to 0.45 .

The results for kappa index point to a reasonable agreement, whereas the weighted kappa indicates moderate agreement 
(Landis \& Koch, 1977). According to the value obtained for the kappa index, it can be understood that NDVI reasonably quantifies the gradient of degradation.

The high number of classes of degradation complicates the separation of neighboring classes in the field (Monteiro et al., 2018). The values obtained for weighted kappa show that, after the effect of these confusions is revealed, the method of digital classification and mapping generates thematic maps with good accuracy.

The indices kappa and weighted kappa obtained for the three calibrations were similar and satisfactory. It is worth pointing out that, among the three digital mappings, the second one was considered, prior to the field campaign, as the one with best relationship between Google Earth images and the digital classification.

These results demonstrate that visual calibration of the model through Google Earth image was consistent. In addition, it confirms the potentiality of application of the methodology because it allows for similar and satisfactory results even when there are doubts between the values of calibrated NDVI.

The analysis of the results, considering the calibration 2 , demonstrates the high level of degradation found in the Limoeiro River Basin, since $96.5 \%$ of the pastures exhibit some degree of degradation (classes I to V) and $69.7 \%$ of all pastures exhibit heavy or more intense degradation (classes I to III).

The results corroborate those obtained by INAES (2015), which mapped the pastures of Minas Gerais, dividing them into four levels of degradation. According to this study, for the Minas Gerais mesoregions of Forest e, Doce River Valley and Belo Horizonte Metropolitan Region, which encompass the Doce River Basin almost entirely, 42.5, 40.9 and $44.7 \%$ of the pastures in activity have a strong degree of degradation, 33.0, 34.5 and $29.2 \%$ exhibit a moderate degree of degradation, and 5.6, 3.4 and $4.8 \%$ are not degraded, respectively.

The land is a provider of various natural resources and processes, such as food production, fiber, control of floods and erosion, water availability and quality, regulation of pests and diseases, carbon sequestration, and regulation of climate and gases (Adhikari \& Hartemink, 2016). Thus, the stage of degradation of the pastures, associated with the area occupied by them $(67.8 \%)$, substantially contributes to the scarcity of resources and to the environmental imbalance observed in the basin. Erosion and reduction of water availability are the most prominently observed in the field.

Pasture areas are more degraded in the middle and upper zones of the terrain; the former portion is more susceptible to erosion, due to the more accentuated slope (Oudenhoven et al., 2015), and the latter can be considered as a zone of recharge (Falkenmark, 2011), which aggravates even more the water problems.

One limitation noted in the methodology is the classification of degraded pastures combined with trees, because trees tend to elevate the value of NDVI, due to their leaf biomass, being classified as class VII. Such limitation can be reduced by using images with more detailed resolutions, but is not a major problem because the area associated with the class VII was smaller than $0.6 \%$ for Calibration 2 .
The methodology was developed considering eight classes of use intensity exerted by pastures, but it can be used if a lower number of classes is satisfactory and, according to the considerations of Monteiro et al. (2018), its accuracy may be increased.

The intensities associated with pasture in the land use capacity classification systems, described by Lepsch et al. (2015), have lower magnitude (classes V, VI and VII). Thus, we recommend that studies comparing land use capacity with its use intensity should employ methodologies that make possible the differentiation of the degree of degradation of agricultural crops in order to provide a more realistic diagnosis.

\section{Conclusions}

1. The methodology of mapping of the land use intensity exerted by pasture through remote sensing was effective in the characterization of eight levels of degradation/land use intensity.

2. The NDVI satisfactorily quantified the gradient of degradation of the pastures.

3. The Limoeiro River Basin was characterized as predominant intensity of use in pastures equivalent to class III (heavily degraded), exerting higher intensity of land use than when adequately managed, leading to serious problems regarding the maintenance of natural resources.

\section{Acknowledgments}

To the Conselho Nacional de Desenvolvimento Científico e Tecnológico (CNPq, Brazil) and Fundação de Amparo à Pesquisa do Estado de Minas Gerais (FAPEMIG) for funding the study, and also to the reviewers and others who have contributed to the study.

\section{Literature Cited}

Adhikari, K.; Hartemink, A. E. Linking soils to ecosystem services: A global review. Geoderma, v.262, p.101-111, 2016. https://doi. org/10.1016/j.geoderma.2015.08.009

Aguiar, D. A.; Mello, M. P.; Nogueira, S. F.; Gonçalves, F. G.; Adami, M.; Rudorff, B. F. T. MODIS time series to detect anthropogenic interventions and degradation processes in tropical pasture. Remote Sensing, v.9, p.1-20, 2017. https://doi.org/10.3390/rs9010073

Alvarez, C. A.; Stape, J. L.; Sentelhas, P. C.; Gonçalvez, J. L. de M.; Sparovek, G. Köppen's climate classification map for Brazil. Meteorologische Zeitschrift, v.22, p.711-728, 2013. https://doi. org/10.1127/0941-2948/2013/0507

Álvarez-Mozos, J.; Campo, M. A.; Giménez, R.; Casalí, J.; Leibar, U. Implications of scale, slope, tillage operation and direction in the estimation of surface depression storage. Soil \& Tillage Research, v.111, p.142-153, 2011. https://doi.org/10.1016/j.still.2010.09.004

Bernardi, A. C. C. de; Grego, C. R.; Andrade, R. G.; Rabello, L. M.; Inamasu, R. Y. Spatial variability of vegetation index and soil properties in an integrated crop-livestock system. Revista Brasileira de Engenharia Agrícola e Ambiental, v.21, p.513-518, 2017. https:// doi.org/10.1590/1807-1929/agriambi.v21n8p513-518

Brasil. Mapa de solos do estado de Minas Gerais. Belo Horizonte: UFV/ CETEC/ UFLA/ FEAM, 2010. 4p. 
Congalton, R. G.; Green, K. Assessing the accuracy of remotely sensed data: Principles and practices. 2.ed. New York: CRC Press, 2009. 200p.

Dias, L. C. P.; Pimenta, F. M.; Santos, A. B.; Costa, M. H.; Ladle, R. J. Patterns of land use, extensification, and intensification of Brazilian agriculture. Global Change Biology, v.22, p.2887-2903, 2016. https://doi.org/10.1111/gcb.13314

Falkenmark, M. Water: A reflection of land use: Understanding of water pathways and quality genesis. International Journal of Water Resources Development, v.27, p.13-32, 2011. https://doi.org/10.1 080/07900627.2010.536943

INAES - Instituto Ernesto de Salvo. Estado da arte das pastagens em Minas Gerais. 1.ed. Belo Horizonte: Ministério da Agricultura, Pecuária e Abastecimento, 2015. 206p.

Landis, J. R.; Koch, G. G. The measurement of observer agreement for categorical data. Biometrics, v.33, p.159-174, 1977. https:// doi.org/10.2307/2529310

Lepsch, I. F.; Espindola, C. R.; Vischi Filho, O. J.; Hernani, L. C.; Siqueira, D. S. Manual para levantamento utilitário e classificação de terras no sistema de capacidade de uso. 1.ed. Viçosa: SBCS, 2015. 170p.

Li, G.; Fu, Y.; Li, B.; Zheng, T.; Wu, F.; Peng, G.; Xiao T. Microcharacteristics of soil aggregate breakdown under raindrop action. Catena, v.162, p.354-359, 2018. https://doi.org/10.1016/j. catena.2017.10.027

MEA - Millennium Ecosystem Assessment. Ecosystems and human well-being: Synthesis. Washington: Island Press, 2005. 137p.

Monteiro, E. de C.; Burak, D. L.; Cunha, A. de M.; Passos, R. R.; Mendonça, E. de S. Visual assessment of pasture degradation: Validation by ground cover and seasonal variation. Revista Ciência Agronômica, v.49, p.174-182, 2018. https://doi. org/10.5935/1806-6690.20180020

Oudenhoven, A. P. E. van; Veerkamp, C. J.; Alkemade, R.; Leemans, R. Effects of different management regimes on soil erosion and surface runoff in semi-arid to sub-humid rangelands. Journal of Arid Environments, v.121, p.100-111, 2015. https://doi. org/10.1016/j.jaridenv.2015.05.015
Pereira, L. F.; Ferreira, C. F. C.; Guimarães, R. M. F. Manejo, qualidade e dinâmica da degradação de pastagens na Mata Atlântica de Minas Gerais - Brasil. Nativa, v.6, p.370-379, 2018. https://doi. org/10.31413/nativa.v6i4.5542

R Core Team. R: A language and environment for statistical computing. 2018. Available on <https://www.R-project.org/>. Accessed on: Dec. 2018.

Rocha Júnior, P. R. da; Andrade, F. V.; Mendonça, E. de S.; Donagemma, G. K.; Fernandes, R. B. A.; Bhattarai, R.; Kalita, P. K. Soil, water and nutrient losses from management alternatives for degraded pasture in Brazilian Atlantic rainforest biome. Science of the Total Environment, v.583, p,53-63, 2017a.

Rocha Júnior, P. R. da; Bhattarai, R.; Fernandes, R. B. A.; Kalita, P. K.; Andrade, F. V. Soil surface roughness under tillage practices and its consequences for water and sediment losses. Journal of Soil Science and Plant Nutrition, v.16, p.1065-1074, 2016. https://doi. org/10.4067/S0718-95162016005000078

Rocha Júnior, P. R. da; Donagemma, G. K.; Andrade, F. V.; Passos, R. R.; Costa, A. S. V. da; Ruiz, H. A. Field-based quality indicators in degraded pasture of the atlantic forest biome. Australian Journal of Crop Science, v.11, p.652-661, 2017b. https://doi.org/10.21475/ ajcs.17.11.06.p326

Sambuichi, R. H. R.; Oliveira, M. Â. C. de; Silva, A. P. M. da; Luedemann, G. Sustentabilidade ambiental da agropecuária brasileira: Impactos, políticas públicas e desafios. Brasília: Instituto de Pesquisa Econômica Aplicada, 2012. 52p.

Schneider, M.; Andres, C.; Trujillo, G.; Alcon, F.; Amurrios, P.; Perez, E.; Weibel, F.; Milz, J. Cocoa and total system yields of organic conventional agroforestry vs. monoculture systems in a long-term field trial in Bolivia. Experimental Agriculture, v.53, p.351-374, 2017. https://doi.org/10.1017/S0014479716000417

Silva, A. P. da; Imhoff, S.; Corsi, M. Evaluation of soil compaction in an irrigated short-duration grazing system. Soil \& Tillage Research, v.70, p.83-90, 2003. https://doi.org/10.1016/S01671987(02)00122-8 